J. Reprod. Fert. (1973) 34, 523-525

\title{
EFFECT OF (+)-INPEA ON CONTRACTIONS OF THE ISOLATED RAT UTERUS EVOKED BY PROSTAGLANDINS
}

\author{
V. S. N. RAO AND P. L. SHARMA \\ Department of Pharmacology, Postgraduate Institute of Medical \\ Education and Research, Chandigarh, India
}

(Received 2nd April 1973)

\begin{abstract}
Summary. The effect of oral $(100 \mathrm{mg} / \mathrm{kg})$ and intraperitoneal (10 $\mathrm{mg} / \mathrm{kg}$ ) administration of (+)-INPEA on contractions of the isolated rat uterus evoked by $\mathrm{PGE}_{1}, \mathrm{PGE}_{2}$ and $\mathrm{PGF}_{2 \alpha}$ has been investigated. Administration of $(+)$-INPEA by both routes increased the sensitivity of the uterus to each of the prostaglandins studied. Since (+)-INPEA appears to be non-toxic, its potentiating action may enable clinicians to use smaller doses of prostaglandins for therapeutic abortion or for the induction of labour.
\end{abstract}

The effect of optical isomers of INPEA ( $\mathcal{N}$-isopropyl-p-nitro-phenyl-ethanolamine hydrochloride) on the contractions of the isolated rat uterus evoked by oxytocin (Saini \& Sharma, 1971) or by prostaglandins (Rao \& Sharma, 1972) has been reported. Laevo (-)-INPEA exhibited a weak antioxytocin activity but had no effect on the responses evoked by prostaglandins. By contrast, $(+)$-INPEA potentiated the action of oxytocin and prostaglandins when added to the bath fluid at a concentration of $1 \times 10^{-5} \mathrm{~g} / \mathrm{ml}$. This study was undertaken to determine whether or not oral and intraperitoneal administration of $(+)$ INPEA in the rat would also potentiate the contractions of the uterus evoked by $\mathrm{PGE}_{1}, \mathrm{PGE}_{2}$ and $\mathrm{PGF}_{2 \alpha}$.

Eighty-four female albino rats of the Charles-Foster strain weighing 150 to $200 \mathrm{~g}$ were used in the study. Oestrus was induced by a subcutaneous injection of $200 \mu \mathrm{g}$ oestradiol dipropionate $15 \mathrm{hr}$ before starting the experiment. Three sets of experiments involving the three prostaglandins, $\mathrm{PGE}_{1}, \mathrm{PGE}_{2}$ and $\mathbf{P F G}_{2 \alpha}$, were performed, using seven animals in each group for each mode of administration. The first group of animals served as controls, the second group received orally $100 \mathrm{mg}(+)-\mathrm{INPEA} / \mathrm{kg}$ in $10 \mathrm{ml}$ distilled water and the third group received intraperitoneally $10 \mathrm{mg}(+)-\mathrm{INPEA} / \mathrm{kg}$ in $5 \mathrm{ml}$ normal saline $(0.9 \%$ $\mathrm{w} / \mathrm{v}), 1 \mathrm{hr}$ before starting the experiment.

The animals were stunned by a blow on the head and a small piece ( 1 to 2 $\mathrm{cm}$ ) of the cervical end of the uterine horn was removed and suspended in an organ bath $(10 \mathrm{ml})$ containing aerated de Jalon's solution at $29^{\circ} \mathrm{C}$. After an equilibration period of $30 \mathrm{~min}$, uterine responses to graded doses of each of the three prostaglandins were recorded on a Servoscribe (R.E. 511.20 potentio- 
Table 1. Potentiating effect of oral and intraperitoneal ( + )-INPEA on responses of the isolated rat uterus evoked by prostaglandins

\begin{tabular}{|c|c|c|c|c|c|c|}
\hline \multirow{3}{*}{ Drug } & \multirow{3}{*}{$\begin{array}{c}\text { Dose } \\
(n g / m l)\end{array}$} & \multirow{3}{*}{$\begin{array}{c}\text { Control } \\
(\text { mean } \pm S . E .)\end{array}$} & \multicolumn{4}{|c|}{ Height of contraction $(\mathrm{mm})$} \\
\hline & & & \multicolumn{2}{|c|}{ Intraperitoneal* } & \multicolumn{2}{|c|}{ Oral† } \\
\hline & & & Mean \pm S.E. & $\mathrm{P}$ value & Mean \pm S.E. & $\mathbf{P}$ value \\
\hline $\mathrm{PGF}_{2 \alpha}$ & $\begin{array}{r}5 \\
10 \\
20\end{array}$ & $\begin{array}{l}10 \pm 0 \cdot 4 \\
18 \pm 2 \cdot 2 \\
24 \pm 2 \cdot 7\end{array}$ & $\begin{array}{l}22 \pm 2 \cdot 6 \\
32 \pm 3 \cdot 3 \\
39 \pm 3 \cdot 6\end{array}$ & $\begin{array}{l}<0.01 \\
<0.01 \\
<0.01\end{array}$ & $\begin{array}{l}16 \pm 1 \cdot 3 \\
25 \pm 1 \cdot 4 \\
32 \pm 2 \cdot 0\end{array}$ & $\begin{array}{l}<0.01 \\
<0.05 \\
<0.05\end{array}$ \\
\hline $\mathrm{PGE}_{2}$ & $\begin{array}{l}10 \\
20 \\
40\end{array}$ & $\begin{array}{r}4 \pm 0 \cdot 4 \\
11 \pm 1 \cdot 0 \\
22 \pm 2 \cdot 0\end{array}$ & $\begin{array}{l}15 \pm 0.6 \\
22 \pm 1 \cdot 6 \\
30 \pm 2 \cdot 5\end{array}$ & $\begin{array}{l}<0.01 \\
<0.01 \\
<0.05\end{array}$ & $\begin{array}{l}11 \pm 0.7 \\
17 \pm 1.0 \\
25 \pm 2.6\end{array}$ & $\begin{array}{l}<0.01 \\
<0.01 \\
<0.50\end{array}$ \\
\hline $\mathrm{PGE}_{1}$ & $\begin{array}{l}10 \\
20 \\
40\end{array}$ & $\begin{array}{r}4 \pm 0 \cdot 2 \\
6 \pm 0 \cdot 5 \\
10 \pm 1 \cdot 2\end{array}$ & $\begin{array}{l}14 \pm 1 \cdot 1 \\
20 \pm 1 \cdot 4 \\
26 \pm 1 \cdot 8\end{array}$ & $\begin{array}{l}<0.01 \\
<0.01 \\
<0.01\end{array}$ & $\begin{array}{r}7 \pm 0.6 \\
13 \pm 0.9 \\
22 \pm 1.3\end{array}$ & $\begin{array}{l}<0.01 \\
<0.01 \\
<0.01\end{array}$ \\
\hline
\end{tabular}

Results are the mean of seven experiments in each group.

* (+)-INPEA, $10 \mathrm{mg} / \mathrm{kg}$.

$\dagger(+)$-INPEA, $100 \mathrm{mg} / \mathrm{kg}$.

metric recorder), using a force displacement transducer. The resting tension of the tissue was set at $0.5 \mathrm{~g}$.

Solutions of the prostaglandins were freshly prepared. They were first dissolved in phosphate buffer ( $\mathrm{pH} 7 \cdot 4$ ) and further dilutions were made in isotonic saline. Levels of significance were calculated using Student's $t$ test.

The results are summarized in Table 1 and Text-fig. 1. It is apparent that both oral and intraperitoneal administration of $(+)$-INPEA increased the amplitude of contractions evoked by all three prostaglandins compared to the controls. The results were, with one exception, statistically significant $(P<0 \cdot 05)$.

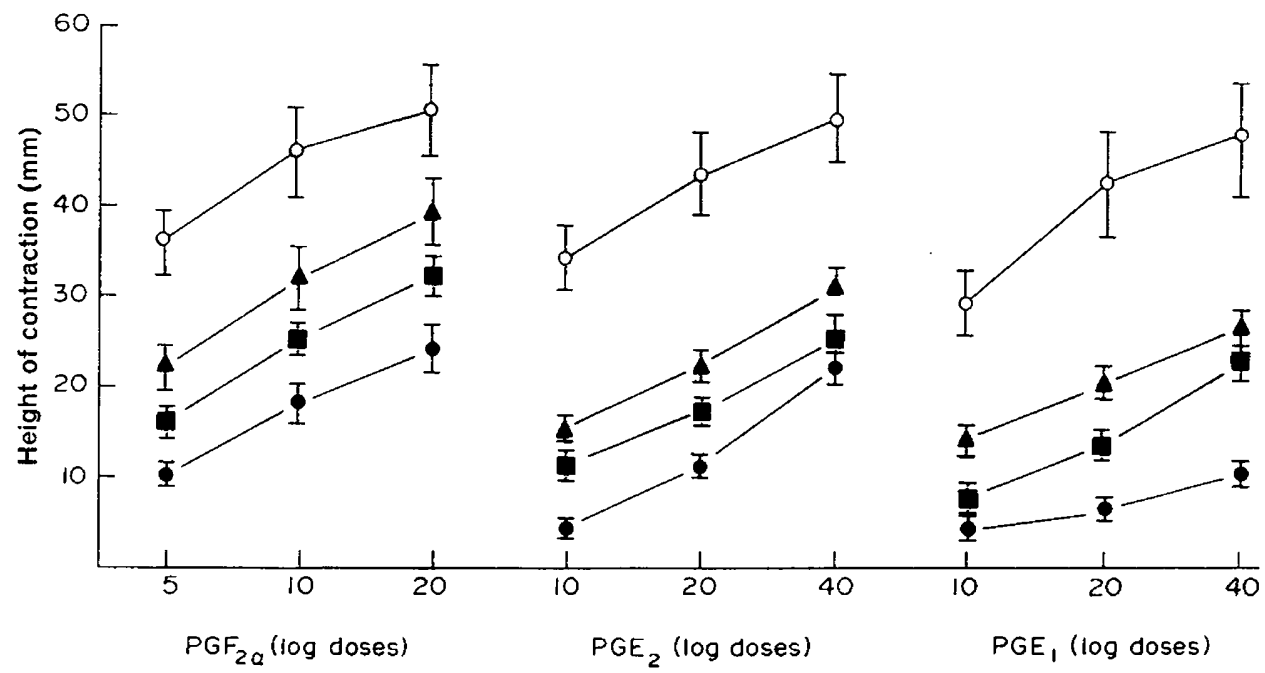

TEXT-FIG. 1. Potentiation by (+)-INPEA of the responses evoked in isolated rat uterus preparations by $\mathrm{PGF}_{2 x}, \mathrm{PGE}_{2}$ and $\mathrm{PGE}_{1}$. For purposes of comparison, the potentiation of prostaglandin responses by the addition of $(+)$-INPEA $\left(1 \times 10^{-5} \mathrm{~g} / \mathrm{ml}\right)$ to the nutrient fluid has been incorporated. Control; $\boldsymbol{\omega}$, oral; $\boldsymbol{\Delta}$, intraperitoneal; $O$, bath. Each point is the mean of seven experiments. 
The present study shows that oral or intraperitoneal administration of (+)-INPEA sensitizes the uterine tissue to the action of prostaglandins. This potentiating effect of (+)-INPEA is of interest in view of the therapeutic application of prostaglandins for inducing labour and for the termination of pregnancy. The doses at which prostaglandins are usually effective often produce severe, undesirable, and at times intolerable side-effects. Unpublished data (W. Murmann, personal communication) reveal that (+)-INPEA did not show any toxicity either in acute tests (mice and rats) or in chronic studies (rats and dogs dosed orally for 180 days). The drug also appears to be non-toxic in human subjects. The intravenous administration of $2 \mathrm{mg}(+)-\mathrm{INPEA} / \mathrm{kg}$ to 'normal' men changed neither heart rate nor blood pressure (Pivea \& Ongari, 1968). A single oral dose (700 $\mathrm{mg})$ and a single intravenous dose $(75 \mathrm{mg})$ did not produce any untoward effect in hypertensive subjects (Gilfrich, Rahn \& Schmahl, 1969). These studies indicate that the drug may be quite safe for clinical use. Since (+)-INPEA markedly potentiates the uterine responses evoked by $\mathrm{PGE}_{1}, \mathrm{PGE}_{2}$ and $\mathrm{PGF}_{2 \alpha}$, the use of (+)-INPEA may enable clinicians to use smaller doses of prostaglandins for therapeutic purposes, thus limiting their side-effects. Further work to evaluate the therapeutic effectiveness of INPEA and the mechanism of potentiation is in progress.

The authors are grateful to Dr J. E. Pike of Upjohn Co., U.S.A., and to Selvi and Co., Milan, for the generous gifts of prostaglandins and (+)-INPEA, respectively.

\section{REFERENGES}

Gilfrich, H. J., RahN, K. H. \& Schmahl, F. U. (1969) A comparison of the antihypertensive action of propranolol and the optical isomers of $\mathcal{N}$-isopropyl-p-nitrophenyl ethanolamine (INPEA). Pharmacol. clin. 2, 30.

Pivea, M. \& ONGARI, R. (1968) Contribution to the clinical evaluation of $\beta$-adrenergic blocking drugs. 1 -p-nitrophenyl-2 isopropyl aminoethanol (INPEA) as an antagonist of catecholamines in normal persons and in coronary disease patients. ArzneimittelForsch. 18, 179.

Rao, V. S. N. \& Sharma, P. L. (1972) Potentiating effect of d-INPEA on prostaglandins $\left(\right.$ PGF $_{2 \alpha}$ and $\mathrm{PGE}_{2}$ )-evoked contractions of the isolated rat uterus. Eur. Fnl Pharmac. 20, 363.

Saini, R. K. \& Sharma, P. L. (1971) Antioxytocin activity of propranolol, INPEA and their optical isomers on the isolated rat uterus. Eur. Fnl Pharmac. 14, 399. 